\title{
Crisis of Solidarity?: Changing Welfare and Migration Regimes in Sweden
}

\author{
Magnus Dahlstedt and Anders Neergaard \\ Journal Article
}

\section{Tweet}

N.B.: When citing this work, cite the original article.

Original Publication:

Magnus Dahlstedt and Anders Neergaard, Crisis of Solidarity?: Changing Welfare and Migration Regimes in Sweden, Critical Sociology, 2016.pp.1-15.

http://dx.doi.org/10.1177/0896920516675204

Copyright: SAGE Publications (UK and US)

http://www.uk.sagepub.com/home.nav

Postprint available at: Linköping University Electronic Press

http://urn.kb.se/resolve?urn=urn:nbn:se:liu:diva-134455

LINKÖPINGS

UNIVERSITET 


\title{
Crisis of Solidarity? Changing Welfare and Migration Regimes in Sweden
}

\section{Magnus Dahlstedt}

Linköping University, Sweden

\section{Anders Neergaard}

Linköping University, Sweden

\begin{abstract}
Europe is in crisis. In recent years, there has been a rise of xenophobic parties in a number of European countries. While arguing that there is indeed a European crisis, this article focus on the Swedish take of the crisis. The aim is to contribute to the understanding of migration, from a Swedish vantage point. This orientation has particular significance, since Sweden has traditionally been extolled as defending human rights and multiculturalism by opening its doors to refugees - the so called Swedish exceptionalism. Reality, however, is quite different and former policies are contested, raising the question whether this signals the end of this exceptionalism. In Sweden, on-going processes are transforming the core social fabric of what was previously known as the Swedish model. It is potentially a bellwether for the transformation of a previously inclusive democratic society into something quite different, in which 'the Other' increasingly plays a defining role.
\end{abstract}

\section{Keywords}

racism, racialization, Swedish model, migration regime, welfare regime, multiculturalism, inclusion, exclusion

\section{Introduction}

The Mediterranean graveyard of refugees and the permanent migration of Roma in the European internal market are increasingly becoming symbols of a Europe in crisis - but they are not the causes.

There are few scholars who would disagree with the statement that Europe is in crisis. However, in framing the European crisis, disagreement runs rampant. We would argue that parts of the European crisis might be linked to a consensus on neoliberal austerity, played out through high and increasing levels of unemployment, as well as to increasing inequalities in property, income, and welfare. In this context, the crisis is aggravated by a European Union (EU) political regime which inflicts the politics of neoliberal austerity European population, despite what seem to be generally recognized within the scholarly community, as failing and worsening results. In addition, the EU project as a whole, with its grandiose framing of civilization, peace, prosperity, and integration, is in a crisis of legitimacy.

The questioning of the EU's legitimacy goes against both neoliberal economic policies and the integration and standardization of politics per se. There is an increased mobilization against the project of the EU. While these mobilizations have been politically weak in most countries, there have also been anti-austerity mobilizations, for instance in Spain, Greece, and Portugal. Instead, the more successful political mobilizations against the EU are through extreme right-wing parties (ERP). In the last European parliamentary elections, the National Front (FN) of France, 
the United Kingdom Independence Party (UKIP), and the Danish People's Party (DPP) had large parliamentary success, becoming among the largest parties representing their respective countries in the European Parliament. Recently, only 30000 votes stopped the Freedom Party of Austria's (FPÖ) presidential candidate from assuming presidency in Austria, although he may have a second opportunity because the Supreme Court may decide to rerun the election due to voting irregularities. This result was then followed by the 'Brexit' triumph in the UK referendum to remain in or to leave the EU. While European integration is a general part of the political programme of these extreme right-wing parties, there is one central, distinctive interpellation that characterizes these parties, both in respect of the EU itself and in respect of their national programmes, namely xenophobia and exclusionary racism. These extreme rightwing parties thrive on Europe's internal migrations, as epitomized by Roma EU migrants, as the political, economic, and military crises in the south and south east of Europe lead to large numbers of refugees seeking safe haven in Europe. These parties, while being marginal in the parliaments of most European countries, have successfully influenced mainstream political agendas. On the EU level, as in many European countries, the idea of a liberal, and at least partially inclusive, multicultural project is dead or rapidly dying.

While arguing that there is indeed a European crisis, this article will focus on the Swedish view of the crisis. The aim of the article is to contribute to an understanding of the contemporary crisis in Sweden. The focus on Sweden is of particular significance as Sweden has traditionally been extolled as an inclusive society that defends human rights and multiculturalism by opening its doors to those seeking refuge and a new life. This makes the Swedish welfare regime appear somewhat exceptional - the Swedish exceptionalism. However, reality is quite different, and today - in the context of Europe's so-called 'refugee crisis' post-2015 - former migration policies are contested fiercely when developing new, restrictive policies on migration, thus raising the question of whether this development actually signals the end of Swedish exceptionalism (Schierup and Ålund, 2011). As shown in this article, the crisis in contemporary Sweden, and the possible end of Swedish exceptionalism, can be traced back to the last two decades of neoliberal policy shifts that have transformed the core social fabric of what was previously known as the (Social Democratic) Swedish welfare model. This shift is potentially a bellwether for the transformation of a previously inclusive liberal democratic society into something quite different, in which the exclusion of the migrant 'Other' plays an increasingly defining role - although the migrant 'Other' has also been excluded in the past (cf. Ålund and Schierup, 1991).

Following this introduction, the article explores the political shifts in the policy areas of labour market and urban policy, as well as the rapprochement between neo-liberalism and neoassimilationism, by putting Sweden in a European context. This article sets out to analyze these changes in Sweden inspired by a dual critical perspective that is characterized on the one hand by a materialist, historicizing, sociological approach, and on the other by critiques of textual objects, ideologies, and discourses. We argue that it is the relationship of power, materially and discursively produced, that is at the core of the crisis in which Swedish exceptionalism is evaporating. The article explores the centrality of migration, ethnicity, and 'race' in shaping how issues of inclusion and exclusion, and super-ordination and subordination, are discursively produced and materially organized.

\section{Migration and Racialization - A Critical Analytical Frame}

As in other research fields, migration and ethnic studies, including the more Anglophone race relations sociology, are characterized by theoretical struggles. The research field was long 
dominated by perspectives which viewed ethnicity as something inherent and pre-established, and which emphasized migrants or ethnic minorities in terms of discrepancies and shortcomings. Language deficiencies, lack of knowledge about how the host society works, lack of cultural competences, etc. were presumed to hinder integration (see also the critique in CCCS, 1982; Grillo, 1985). In a number of important contributions, Miles $(1982,1989)$ argued that the prevailing race relations sociology adopted concepts such as race and ethnicity in an overtly uncritical manner. This resulted in research that pursued an agenda that was wholly dictated by servicing the needs of the state in managing migration and migrant Others. However, a more critically oriented agenda addresses issues of migration and ethnicity from a more pronounced power and relational perspective.

Inspired by this research, we emphasize how relations of inclusion and exclusion, and of superordination and subordination, are constructed through references to migration, ethnicity, and 'race' (Neergaard, 2009). In the foreground, we therefore find issues about resources, demarcation, normalization, hierarchy, decision making, and interpretive disputes, in which it is the configuration of power relations in society, as opposed to the migrants or the ethnic minorities themselves as 'the problem', that is the departure point. As these transitions and boundaries are created, different characteristics are used to differentiate those who 'belong' from those who do not belong (cf. Said, 1978; Hall, 1992; Dyer, 1997). The questions then are: In what ways do the issues of ethnicity and 'race' arise, and what are the consequences for different sectors of society - the labour market, housing market, educational sector, judicial system, politics, the media, and everyday life? Here, the idea of constitutive social and political processes is fundamental to contemporary research. There is an on-going explicit and implicit creation of social difference in which 'race' and ethnicity are constituted and reconstituted daily at every level of social practice. Thus the terms 'ethnicization' (Ålund and Schierup, 1991) and 'racialization' (Miles, 1989) refer to the processes that make physical appearance and culture key factors in the separation, prioritization, and allocation of symbolic as well as material resources in society (Miles and Brown, 2003). A working life and housing are two of the most fundamental concerns in a society in which power structures and social arenas are interrelated and interwoven both symbolically and materially.

We have seen how politicians and political parties, media and academia, in their quest for popular support and legitimacy, have labelled 'outsiders' as a social problem. In the US, the phrase 'playing the race card' was coined to describe politicians trying to boost their appeal and gain electoral support by directly or indirectly alluding to popular preconceptions about 'race'1 (Thompson Ford, 2008). Thus it is vital not to view 'ethnicity', 'immigrants', 'asylum seekers', or 'refugees' as neutral words, but as part of the larger conception of the world (ideology or discourse, if you will) that also highlights, conceals, or draws our attention in some directions more than others - illegal and sham migrants are perhaps two of the most obvious examples.

Such conceptualisations are reflected in a substantial part of research, which has directly or indirectly absorbed some of the basic tenets of partially framing the European crisis as a migration and ethnic problem. In this article, we posit the necessity of challenging this understanding from a critical perspective. We disagree with the assumption, often taken for granted, that something external threatens the fabric of Europe, its countries, and (in this article) Sweden. This threat is often located through a rhetorical chain in which migrants, especially ethnicized or racialized migrants, are the problem itself, or the cause of the growth of the ERPs. Instead we argue that - borrowing from Shakespeare - 'Something is rotten in the state of Denmark' and expand it to Europe in general, and to the country Hamlet was observing, just 
across the Oresund Strait, namely Sweden. The crisis in Europe, like the crisis in Sweden, is generated internally, and can neither be explained away by the presence of the refugees and migrants themselves, nor by the xenophobia and racism of the extreme right. Inspired by a dual critical commitment, we analyse the rapid changes in Sweden, arguing for the need to highlight the material as well as discursive dimensions of social relations, constituted and constructed through migration, ethnicity and 'race'.

\section{A Changing Swedish Welfare Regime}

The terms 'Swedish model' and 'Swedish exceptionalism' are ways of framing the peculiarities that many scholars have highlighted in the organization of the Swedish welfare state. One central feature underlying the processes that these terms aim to embody has often been associated with the long hold on government by the Swedish Social Democratic Party (SAP) (1932-1976, 1982-1991, 1994-2006, 2014 to the present). This dominance is often linked specifically to the combination of labour market and welfare policies, and to a neo-corporatist, class-based understanding of societal actors (Esping-Andersen, 1990). Another, later feature often included in an understanding of the 'Swedish model' is that of gender politics, in its broad definition. In the Scandinavian countries, there has been a particular state feminism, closely related to the welfare regime, which focuses on labour market participation and welfare service provisions, not the least of which are related to reproduction, parental leave, social insurance, childcare and care for the elderly, financial gender equality, and political representation (Borchorst and Siim, 2008; Sainsbury, 1996). A third feature of the Swedish model comprises the international migration and ethnic relations' regime. This distinguishes Sweden substantially from the other Nordic countries. Firstly, because Sweden is among the European countries with the highest proportion of foreign-born citizens in its population, both in total and in terms of non-EU migrants. ${ }^{2}$ Secondly, and more importantly, is that a regime of inclusionary multiculturalism has been established in Sweden, and to some extent in the UK and the Netherlands, which has been relatively encompassing (Castles and Miller, 2009).

The Swedish welfare model, developed during the post-war period, has had quite an astonishing international reputation as a successful 'middle course' between capitalism and socialism. Inspired by Keynesian ideas, the Swedish welfare model has emphasized employment, including government intervention to secure demand, and active labour market policies. Low unemployment and a high degree of commodification have been complemented by extensive social insurances, and public services (Esping-Andersen, 1990).

However, starting in the late 1980s, several of the cardinal principles underpinning the Swedish model have been challenged politically. The model has been criticized for its alleged inefficiency and highly centralized micro-management which stand in the way of individual initiative (Boréus, 1994). Over recent decades, the Swedish model has undergone a radical transformation which has accelerated following the deep economic crisis of the early 1990s (Lindvall, 2004). Structural reforms that reconfigured the Swedish welfare regime have been implemented by both the Social Democratic government (1982-1991 and 1994-2006) and by the centre-right government (1991-1994 and 2006-2014). As in many other countries in Europe and other parts of the world, the Swedish welfare model has transformed towards a model that emphasizes individual autonomy, initiative and freedom of choice vis-à-vis governmental control, and endeavours to achieve equality and the redistribution of societal resources (Dahlstedt, 2015).

Flexibility, innovation, and international competitiveness constitute the overriding goals guiding this development (Jessop, 2002; Schierup et al., 2006). In order to make the labour market more flexible and competitive, economic policy is given precedence over social policy. 
This implies that social welfare expenditure is viewed more in terms of cost of production than as a means to redistribute resources. Both social and labour market policy are primarily focused on the supply side of the labour market, in an attempt to create a more competitive 'knowledge economy'. The transfer system is made more cost-effective in order to promote a 'climate of enterprise'. State intervention by means of social policy measures is shrinking and is viewed less as a means of protecting citizens against the forces of an unregulated market economy.

Even if it is not a matter of a complete regime shift, in the sense of the traditional Swedish model being replaced by a completely new model, it is nonetheless possible to discern a development whereby Sweden, in a number of respects, seems to be moving towards a new welfare regime; one that is shaped less by social democratic and more by neoliberal features. The welfare of citizens, which, during the golden age of the Swedish model, was guaranteed by the transfer and social insurance systems of the welfare state, is once again increasingly determined by the market value of work (Esping-Andersen, 1990). The shape of a new Swedish model is emerging which emphasizes the duties of citizens over their rights (Junestav, 2004; Schierup et al., 2006).

\section{Labour Market Policy - From Right to Responsibility}

The changes to the Swedish welfare model have effectively taken place through labour market policies over the past two decades (Sandberg, 2013). The right to work was one of the central foundations of the traditional Swedish model. The general Swedish welfare state which took shape following World War II was based on a labour market policy doctrine known as the work line: on one hand, full employment, in the sense that, as far as possible, everyone who was capable should be in work, and on the other hand, a solidarity-based wage policy with an objective to level out wage differentials. This solidarity-based wage policy was in turn founded on a strong centralized collective bargaining system involving employers and trade unions (Esping-Andersen, 1990). However, the labour market policy of the traditional Swedish model underwent quite dramatic changes beginning in the 1980s with the Social Democratic government's dismantling of the central features of Keynesian infrastructure, and accelerating between 1991 and 1994 and after 2006 with right-wing governments.

Labour market policy discourse of the 1990s shows a distancing from what Levitas (1998) calls the 'redistribution discourse' towards an increasing reliance on both the social integration and moral underclass discourse. In this process, the main challenge is described as developing measures aimed at lifting the unemployed from 'passive' dependency on benefits to an 'active' occupation. In order to succeed with this 'activation', a repertoire of interventions was made in order to improve the 'employability' of the unemployed (Garsten and Jacobsson, 2004). At the same time, an increasingly segregation, particularly in the metropolitan areas, created a strong concern about growing levels of 'exclusion', with the excluded groups being at risk of developing a mentality that separated them from the rest of society (Junestav, 2004; Hörnqvist, 2010).

The policies of labour market activation developed since the 1990s appear as complex, neoliberal forms of governing: on the one hand, empowering - striving to motivate and release the inner creativity of the individual, and on the other hand, disciplinary - emphasising work as an obligation (Hörnqvist, 2010). In the traditional Swedish model, there was also a strong emphasis on work - all those who were able to work were expected to work. However, the obligation to work was balanced by a government-generated demand for labour, the solidaritybased wage policy's efforts to ensure a reasonable wage level, and by the social insurances and services for those whom, for various reasons, were unable to get a job (Junestav, 2004). 
In the first finance plan of the Social Democratic government in the 1990s, the top priority shifted from full employment to price stability - this was the first time since the aftermath of the depression of the 1930s that price stability, rather than full employment, had become the main priority (Meidner, 1999). Labour market policy developed as the 1990s progressed and came to individualize the question of a citizen's right to work. There was a change from a stateoriented form of governing to one that was more oriented towards the individual. Work is transformed here into an issue of the individual's own qualifications and characteristics, and ambitions and abilities. 'Passive' benefits were replaced by 'employment-activating' interventions, making the unemployed more employable (cf. Garsten and Jacobsson, 2004; Dahlstedt et al., 2015). Increased levels of responsibility and more demands were placed on the individual job applicant, while the state increasingly disclaimed responsibility for the outcomes of the labour market policy.

From a comparative perspective, Sweden is doing quite poorly in respect of differences in unemployment and labour market participation between non-racialized persons with a Swedish background and racialized persons with a foreign background. This has increased particularly since the 1990s (cf. Schierup et al., 2015; Likic-Broric et al., 2015). There are a number of different explanations for this, for instance the focus of the shifting economic policies from full employment towards price stability. In the labour market this shift was characterized by moving away from a situation of high employment and access to social insurance, which in the worst sectors of the economy concerned wages and working conditions, towards a situation of high unemployment and permanent insecurity, which often prevented access to (relatively) more generous social insurance (Neergaard, 2016). More specific explanations, in some ways repeating the same tensions, highlight discrimination in various forms or human capital deficits (Behtoui and Neergaard, 2010). The new version of the work line policies that has dominated labour market politics during the last decades has predominantly focused on disciplining Swedes with a foreign background, in a context where there has been a low demand for labour. The situation of high unemployment and lower labour market participation is only partially compensated for by welfare provisions that give rise to what could be called an 'ethnification' (Ålund and Schierup, 1991) or 'racialization' of society (Miles 1993). Aside from higher unemployment and lower labour market participation, these differences are reproduced within employment through ethnic and racialized segmentation, and through processes of informalization restructuring the labour market in general, but particularly affecting racialized migrants (cf. Likic-Broric et al., 2015).

\section{Neoliberal Labour Migration}

While Sweden was one of the major European emigrant countries until the early 20th century (Massey, 1988), the situation changed rapidly following World War II. Immigration was initially made up of refugees from the World War II, and later on refugees from Soviet aggression in Eastern Europe, labour migration from the southern and eastern economic peripheries of Europe, and Nordic, especially Finnish, migration facilitated by a passport union with free movement (Svanberg and Tydén, 1998; Lundh and Ohlsson, 1999; Frank, 2005). These migrations took place during a time when labour demand was exceptionally strong in declining sectors such as agriculture and domestic work, and in expanding sectors such as industry and services. Labour demand accounted for both higher labour market participation rates of migrants and an increasing labour market participation of Swedish-born women (Knocke, 2000; Schierup et al., 2006). Already at the end of this period it became clear that while strong assimilationist policies had been slowly replaced by multiculturalist policies, Sweden did not adopt a model of guest worker or temporary refugee migration (Ålund and Schierup, 1991). The policies were geared towards settling migrants in Sweden. With the economic crisis of the 1970s, labour migration ceased due to the neo-corporatist arrangement 
whereby the working class Swedish Trade Union Confederation, LO, invoked its informal veto power. From this time on, refugee/family reunification migration dominated, although an 'exception clause" ${ }^{3}$ was invoked for the first time by a centre-right-wing government (197682), and again by a Social Democratic government (1989-91), thus limiting refugee migration. Both times, the exception clause was supported by the social democrats and the conservatives, and opposed by the left and the liberals (Spång, 2008).

Despite this limit on refugee migration, there is ample evidence to argue that Sweden's asylum and refugee policy has been fairly non-restrictive in the European context, and has been coupled with quite fast and straightforward possibilities for naturalization (Qvist et al., 2015). Furthermore, issues of asylum and refugee policy have crossed the left-right divisions of the Swedish parliament, where more restrictive policies supported by the Social Democratic Party and the Moderate Party (which oscillates between conservative and neoliberal ideology) have been challenged not only by the Left Party and the Green Party (both generally closer to the social democrats), but also by the Christian democrats, the Liberal and the Centre (traditionally rural-based) parties (the latter three generally closer to the Moderate Party). Together with social movements such as churches, anti-racist and migrant organizations, and public service trade unions, these parties have managed to maintain a fairly non-restrictive asylum and refugee policy (Spång, 2008).

Since the end of 2008, one of the strictest labour migration policies of the Organisation for Economic Co-operation and Development (OECD) was changed into the most liberal policy (OECD, 2011). What makes this policy unique is that it is almost completely employer-driven (Calleman and Herzfeld Olsson, 2015). If some basic formal requirements are fulfilled, then neither government authorities nor trade unions have any real influence in granting labour permits. The labour permits granted are based on a non-binding offer that the labour migrant applicant has as a basis for travel, which means that wages and working conditions may be changed by the employer, but if they do, then the labour migrant has the option of either accepting poorer working conditions or returning home. In addition, the permits are tied to the employer. The labour migrant's right to work and to stay in the country ends if the employment is terminated by the employer, unless the prospective employee finds other work within three months (Calleman and Herzfeld Olsson, 2015; Cerna, 2009).

Labour migration reform is fairly recent, and so far there have been fewer than 20000 permits a year, quite evenly distributed among seasonal work, employment with low skill requirements, and highly skilled, particularly Information and Communications Technologies (ICT), employment. Still, there are a number of reports that demonstrate the vulnerability of labour migrants as well as abuse by employers (Woolfson et al., 2012). The 2008 labour migration reform marks a new direction in Swedish migration policy: the country is more open to labour immigration, yet fully committed to filling the needs of employers, and designed in the form of managed, temporary, circular migration (Bevelander et al., 2014; Qvist et al., 2015). While asylum and refugee policies have not been adversely affected by the reform, there have been government intentions of making kin migration permits more difficult to obtain, and prioritizing temporary labour migration. One possible effect of these developments is the establishment of a migration regime based on reducing permanent migration and increasing temporary migration.

\section{Urban Policy - Stigmatization and Polarization}

The transformation of Swedish welfare policy during the last decades is also highly visible in urban policy. At the beginning of the 2000s, there was a lively debate about the situation in 
suburban areas where attention had been drawn to areas of a large-scale housing project of the 1970s, the so-called Million Programme. Right from start, these areas were treated in public debate as a problem, defined in terms of social and/or ethno-cultural Otherness (Molina, 1997). In the 1970s, the Million Programme was described as being different, primarily in social terms. Later on, the discourse gradually changed, and most of the challenges that had arisen and been interpreted previously in social terms, were now interpreted in terms of ethnicity or migration. In the public debate, there were arguments about the Million Programme areas developing into parallel societies, with their own rules and norms, and being decoupled from the rest of Swedish society.

At the turn of the new millennium, the Million Programme was once more seen as a problem, this time in terms of 'areas of exclusion'. In this context, it is imagined that a particular mentality was taking shape in these multi-ethnic suburbs - a 'culture of exclusion' (Dahlstedt, 2015). The Million Programme is still described as problematic and different, but not primarily due to the social or ethnic differences of the residents, but rather due to particular cultural expressions such as welfare dependency, alienation, and distrust. Although the high level of unemployment was seen as an urgent problem in these 'areas of exclusion', once it had taken shape the specific morality that these socio-economic conditions generated was seen as having a dynamic of its own. In this representation, the 'culture of exclusion' is thus divorced from the wider political, social, and material context. In summary, the suburban residents were themselves made responsible for their own exclusion.

An issue repeatedly raised in urban policy discourse since the late 1990s is how to get the suburban residents to transform their 'culture of exclusion' into a culture of diligence, confidence, employability, and enterprise, in keeping with the surrounding Swedish society (Andersson and Molina, 2003).

This representation of the problems of 'areas of exclusion', and the proposed solutions to these problems, has several parallels to the 'moral underclass' discourse that has been quite influential in the political debate in other countries, for example Britain and the US (Levitas, 1998). As in the 'moral underclass' discourse, the primary focus is on the various shortcomings and responsibilities of the 'excluded', rather than on the hierarchies and inequalities of the economy or society in general (cf. Schierup et al., 2015).

However, in Swedish society, exclusion is not represented as a fringe phenomenon located in the outskirts of the large cities. Rather, exclusion allegedly casts its dark shadow on Swedish society in its entirety. This way of imagining exclusion as a threat is reminiscent of another menace that has set the global geopolitical climate in the 21st century, namely terrorism. This security discourse has led to the government targeting suburban areas, particularly those inhabited by Muslim migrants, and searching for potential terrorists (cf. Flyghed et al., 2011). In both these discourses the threats lie not only 'out there', but also here, in our midst. Although the sources of these alleged threats cannot be identified with exactitude, they are said to originate just from the outskirts of large cities. In public debate, city outskirts are depicted as nurseries for 'cultures of violence', representing a vital threat to Sweden's core values. One of these threats, widely discussed in public debate, is the supposedly 'patriarchal culture' that flourishes in multi-ethnic suburbs and is portrayed as female suburban residents being kept in their homes by male dominance. Due to exclusion, there is a looming risk that this mentality may spread to other urban areas as well.

Recent uprisings of youth in European cities have sparked a debate on urban revolts across Europe. Also, in Swedish cities, the multi-ethnic suburb has become the site of contestation and 
resistance, not least among urban youths, whose lives have been hugely affected by welfare changes, increased poverty, stigmatization, and police surveillance (Schierup and Ålund, 2011). In Sweden, urban unrest has recently been expressed in a series of violent uprisings, including setting cars on fire and confrontations with the police. But, as a response to the social conditions and the repressive policies directed at the urban peripheries, there has also been a rise of urban social movements struggling for justice and claiming a right to the city (Kings et al., 2016).

\section{Paradoxes of Swedish Multiculturalism}

While multiculturalism has in many ways been the official policy of Sweden, the substantial outcomes vary. Multiculturalism became a term, which from the late 1960s encapsulated a positive vision of the countries where migrants settled. While always challenged, it still became a central phrase in a Europe that at least partially wanted to distance itself from the legacies of colonialism. Lentin (2012) argues that the development of multiculturalism followed the UNESCO project of scientifically challenging the concept of 'race', and replacing it with a formal non-hierarchical understanding of ethnicity and culture. In doing so, multiculturalism became a government practice which made it possible to manage a society made up of an increasing number of migrants from other continents. While reflecting a vision of coexistence, multiculturalism has been interpreted in a number of ways. In its most trivial form it has been a way of describing European states that are increasingly composed of inhabitants of different cultures. However, the core meaning is related to the policies that make it possible to live in a society inhabited by people of different cultures.

With quite different histories and social formations that represent different welfare and gender regimes, the UK, the Netherlands, and Sweden have often been referred to as early adopters in Europe who have accepted multiculturalism as a means of managing a society with an increasing number of migrants. However, as Lentin (2012) argues, while Europe was trying to move on from some of the darker chapters of its history in which racism was an integral part, its emphasis on ethnicity, culture, and multiculturalism brought about new ways of perceiving these essential aspects. Traditional biological racism was marginalized and mainly linked to the remnants of fascism and peripheral white youth cultures. With multiculturalism grew the selfunderstanding of a Europe that had distanced itself from racism, although behind this façade 'new' (cultural) racisms were (re)formulated.

The zenith of the Swedish welfare regime was parallel with the expansion of multiculturalist policies, which in combination tended to create an image of Sweden as not only being a fairly equal society in terms of class and gender, but also as a success story concerning multiculturalism and the situation of migrants. In Sweden, multiculturalism was already established in the 1970s. However, it was a kind of multiculturalism that was established by the state, and that culturally organized the 'Others' through ethnic and migrant associations which were orchestrated by the state. As Ålund and Schierup (1991) stress, Swedish multiculturalism was (as was the welfare regime) a solidarity project. At the same time, through co-opting neocorporatist practices, the culture of the migrant Others was subordinated to 'Swedish' normality. Thus, Swedish multiculturalism was inclusionary and subordinating at the same time (Mulinari and Neergaard, 2005).

In this paradoxical Swedish version of multiculturalism, there has been a substantial gap between formal and substantive citizenship rights - in terms of civil, social, and political rights. When it comes to civil rights, studies indicate the importance of ethnicity and 'race' in virtually all steps of the juridical process - for instance, racialized migrants are sentenced more often, get tougher sentences, are investigated more thoroughly, and reported more often than the rest 
of the population (Diesen, 2005). These practices are replicated in public discourses that portray migrants as criminals (Elsrud, 2008; Brune, 2004). When it comes to social rights, the on-going processes of informalization of work result in a very precarious situation, particularly for irregular and undocumented migrants. There is racialization of both employment and unemployment. In employment, there is evidence of 'occupational ghettoes'. As for the unemployed, the notion of employability is ethno-culturally and racially coded, in the sense that being employable is more or less synonymous with the adoption of 'Swedish values' (Vesterberg, 2013). In the provision of welfare there is evidence of institutional discrimination that targets certain categories of migrants (cf. Molina, 1997; de los Reyes, 2006; Runfors, 2006). When considering political rights, there are substantial inequalities in terms of participation and political influence which follow ethno-cultural and racial lines (Dahlstedt et al., 2015).

\section{Neo-liberalism and Neo-assimilationism}

Thus, while multiculturalism in the Swedish context implied the implementation of rather progressive reforms concerning the situation of racialized migrants, it was implemented within the framework of a top-down project that reified and segregated without challenging the structural features that produced the racialization. It was however, not the anti-racist or leftist critique of multiculturalism that came to dominate the political debate. At the end of 2010 and the beginning of 2011, three of Western Europe's main conservative leaders, starting with Angela Merkel in Germany, followed by David Cameron in the UK, and later Nicolas Sarkozy in France, took turns in arguing that multiculturalism had failed. After the 2014 European Parliament elections, two of the Extreme Right Parties (ERPs) ${ }^{4}$ - the United Kingdom Independence Party and France's National Front - had the highest number of elected MEPs representing their respective countries, UK and France. Defining multiculturalism as cultural relativism paving the way for Muslim fundamentalism, the critique assigned migrants an identity threatening European nations. The statements of Merkel, Cameron, and Sarkozy could be seen as more explicit confirmation of processes that had already been studied (Brubaker 2001). The notion of social inclusion, defined as social cohesion according to a moral underclass discourse (Levitas, 1998; Schierup et al., 2015), has increasingly replaced the notion of multiculturalism, to the extent that neo-assimilationism has been incorporated in the mainstream political agenda. Using the concept of 'cultural assimilationism' rather than 'neoassimilationism', Schinkel and Van Houdt (2010) describe a process taking place in the Netherlands which, we argue, would also be applicable to Sweden: the rise of a government strategy that they refer to as 'neoliberal communitarianism', which is based on the merging of cultural assimilationism and neoliberalism.

Writing in the aftermath of the European Parliamentary elections of 2014, it is difficult to avoid noting how the ERPs have substantially strengthened their positions. In three countries Denmark, France, and the UK - the parties receiving the most votes were the Danish People's Party, the National Front, and the United Kingdom Independence Party. If we focus on the Nordic countries, the ERPs in the three EU-member countries, received, respectively, 27\% (the Danish People’s Party), 13\% (the Finn's Party), and 10\% (the Sweden Democrats). In addition, if we include the most recent national elections, the Finn's Party received $19 \%$ of the votes (2011), the Progress Party 16\% (Norway 2013), the Danish People’s Party 12\% (2011), and the Sweden Democrats 12.9\% (2014), it is difficult to avoid a discussion about the success of ERPs in the Nordic countries. While the Danish People's Party has never been in government, it is, and has been, the parliamentary base for government and has a strong political influence (Berggren and Neergaard, 2015). In Norway, the government that was formed in 2013 included 
the Progress Party, which contributed no fewer than 7 out of 16 ministers in the government coalition, among others: the ministers of finance, justice, labour and social affairs, children, gender equality, and integration. When considering the Nordic countries as a region, it is difficult to find another European region that can compete in terms of the success of ERPs. What is particularly interesting is that some of the central explanations for the growth of ERPs do not find support in the Nordic case. It is not a region in economic crisis, and apart from Sweden, it is not a region with a high percentage of non-EU migrants.

The term cordon sanitaire, taken from the Belgian decision to limit the political influence of the Vlaams Blok party, refers to practices that exclude ERPs from political influence. However, an effective isolation of such parties cannot focus on the institutional level alone. A more precise analysis is needed that distinguishes actual influence from formal influence. In Sweden, we would argue that the formal influence of the right-wing Sweden Democrats has been quite marginal, despite holding the balance of power between the right-wing and the centre-left-wing blocs. This may be partially explained by bloc politics and by the blatant racist roots of the party, but also through the effects of a quite strong pro-migrant and anti-racist mobilization. However, the formal exclusion of the Sweden Democrats has not automatically led to the exclusion of their political ideas. At times, both right-wing parties and the Social Democratic Party have toyed with rhetoric similar to that of the Sweden Democrats - not least in the context of the refugee situation in Europe since 2015. In the Danish and Norwegian cases the cordon sanitaire has been dissolved, and both the Danish People's Party and the Progress Party have become fully integrated as respectable political parties in their respective countries. In Finland, with one of the lowest percentages of migrants in the EU, yet with the strongest parliamentary representation of an ERP in the Nordic region, the direct formal influence of the right-wing parties is rather low, although comparable rhetoric is pervasive among other parties.

\section{Conclusion}

We conclude by formulating a number of central questions for future research. In his classic work, The Great Transformation, Polanyi (1989/1946) argued that the emergence of fascism and Nazism in the 1920s and 1930s can be seen as alternative forms to communist and the social democratic reaction to the widening influence of the free market economy. Several researchers have observed similarities between the trend that Polanyi described in the Europe of the 1920s and 1930s and the increasing popularity of right-wing populist parties in the last few decades (Dale, 2010; Marquand, 1997).

While it would be contentious to say that the Nordic welfare regime is disappearing, there are certainly a number of processes challenging it. There is an increasing differentiation between the Nordic countries, and a weakening of the social democratic project and its main actor - the Social Democratic Party. Path dependency and Nordic welfare melancholia maintain strong institutional and discursive residues of the project, albeit now more often formulated through forms of welfare chauvinism. It is still an issue for researchers to explore further whether this chauvinism can be seen as a feature of an emerging Nordic model, in which ERPs have a strong foothold in the parliaments as normalized political partners whose rhetoric - barring the most extreme versions - have become an integral part of Nordic politics. While we would argue that Norway, Denmark, and perhaps Finland, have already reached this position, Sweden is teetering. On the one hand, there is an established ERP and a weakening neoliberal right in the Swedish parliament, who after an election loss has become more susceptible to these kinds of politics, and perhaps might even approach the Sweden Democrats. On the other hand, there is a broad mobilization against racism; the growth of at least three parties with an explicitly antiracist agenda, and opinion polls that indicate that racism is among the most important issues in Sweden today. 
On 21 June 2016, the Swedish parliament, with the support of all parties except the small neoliberal Centre Party and the Left Party, passed an interim three-year legislation concerning migration. The changes in migration policy adopted so far include, among other proposals, the following:

- The abolishing of minimum state subsidies for applicants with legally binding rejections.

- The mobilization of police to implement the swift expulsion of applicants with legally binding rejections.

- The use of temporary residence permits - usually for 13 months.

- Linking economic self-sufficiency with both permanent residence permits and family reunification.

Ironically, the second deputy speaker of the parliament, Björn Söder of the Sweden Democrats, presided over the decision, with SD representatives applauding and cheering, which further indicates that despite being exposed to an organizational cordon sanitaire, the political ideas of the SD party have indeed received strong parliamentary support. It is still too early to conclude whether we are seeing a new Nordic model in the making. Perhaps these countervailing tendencies in Sweden are an aspect of 'white melancholia' (Hubinette, 2012: 46): a longing for an imagined era when the social order appeared safe, homogenous, and stable. Or perhaps we are seeing new (post-material) political cleavages supplanting the conflict of labour and capital that is so central in what has hitherto been referred to as the 'Nordic model'.

In these developments, neo-liberalism is linked to the politics of exclusion. Taking the intersectional approach of McCall (2005) as a way of attempting to untangle the dynamics of the politics of exclusion and its effects on migrants, we would argue that a central point of departure is the current change in the welfare regime, particularly in terms of unemployment, income and wealth inequality, privatization, and activation. Until the beginning of the 1990s, Sweden rarely had an unemployment rate above $2 \%$, while in the last few years there has been an institutionalized (seemingly 'natural') unemployment rate of 6-8\%. The shifts in economic policies, starting with the Social Democratic Party's deregulation of Keynesian institutions in the 1980s, and accentuated by right-wing governments in the early 1990s and again from 2006, have not only increased income differences to levels resembling those of the 1950s, but have increased profit share at the cost of wages even more. Finally, the deregulation and privatization of publicly financed welfare services has created tensions between individual market and family-based arrangements on the one hand, and publicly organized welfare and gender arrangements on the other.

Given that we have, despite a number of issues and problems, argued for analyzing the Swedish or Scandinavian/Nordic model, the question is, to what extent is it ending, fragmenting, or restructuring into new forms? While there have always been substantial differences between the countries within the Scandinavian/Nordic model in relation to both welfare and gender regimes, there were still certain aspects that made it relevant to use the concept of a Scandinavian/Nordic model. However, as several scholars have demonstrated (Keskinen et al., 2009; Loftsdóttir and Jensen, 2012), the concept of a Scandinavian/Nordic model can make certain aspects visible while obscuring others. Besides downplaying the role of the Scandinavian/Nordic model globally, it can also obscure the substantial differences between the countries with respect to migration and ethnic relations. Exceptionalism in terms of welfare and gender regimes has decreased with the neoliberal developments during the last two decades. However, perhaps exceptionalism is being partially replaced by a convergence concerning migration and ethnicity, most acutely expressed by the strong ERPs in the Nordic parliaments. Thus, there are definitely grounds for asking why the Nordic countries have become the 
strongest region in Europe when it comes to the number of well-established ERPs, and whether or not this will be part of a new understanding of the 'Nordic model'. And - turning to Polanyi's (1989/1946) analysis of the 1920s and 1930s - it still remains to be seen whether countermovements will rise, challenge, or further support these developments.

\section{Notes}

${ }^{1}$ As a rule, the fundamental concepts are used to highlight socially constructed phenomena, whether they be preconceptions, practices, or the distribution of resources. Despite this, we have chosen to use quotation marks around the word 'race', to emphasize that it concerns social preconceptions, not biology or genetics.

2 17.0\% foreign-born and 22.2\% foreign background 2015 (born in Sweden of foreign-born parents) (Statistics Sweden scb.se).

${ }^{3}$ The exception clause exists within the Aliens' Act (2005:716) and grants the government the right to set the subsidiary protection grounds aside if the pressure on Swedish capacity to take more migrants is considered too high (Johannesson, 2014).

${ }^{4}$ There is no agreement on defining these parties or which parties should be included. 'ERP' is used here to designate parties that are hostile to immigration and immigrants, emphasize law and order, and pursue right-wing economic policies. For a discussion of terminology, see Widfeldt (2014) and Mulinari and Neergaard (2016).

\section{References}

Ålund A and Schierup C-U (1991) Paradoxes of Multiculturalism. Avebury: Aldersholt.

Andersson R and Molina I (2003) Racialization and migration in urban segregation processes. In: Öhman J and Simonsen K (eds) Voices from the North. Aldershot: Ashgate, 161-182.

Behtoui A and Neergaard A (2010) Social capital and wage disadvantages among immigrant workers. Work, Employment \& Society 24: 761-779.

Berggren E and Neergaard A (2015) Populism. In: Dahlstedt M and Neergaard A (eds) International Migration and Ethnic Relations. London: Routledge, 169-199.

Bevelander, P et al. (2014) Världens öppnaste land. Stockholm: Fores.

Borchorst A and Siim B (2008) Woman-friendly policies and state feminism. Feminist Theory 9(2): 207-224.

Boréus, K (1994) Högervåg. Stockholm: Tiden.

Brubaker R (2001) The return of assimilation?. Ethnic and Racial Studies 24(4): 531-548.

Brune Y (2004) Nyheter från gränsen. Department of Journalism, Media and Communication, Gothenburg University.

Castles S and Miller MJ (2009) The Age of Migration. Basingstoke: Palgrave-Macmillan.

Calleman C and Herzfeld Olsson P (eds) (2015) Arbetskraft från hela världen. Stockholm: Delmi.

CCCS, Centre for Contemporary Cultural Studies (ed.) (1982) The Empire Strikes Back. London: Hutchinson. 
Dahlstedt M (2015) The politics of making demands. International Journal of Politics, Culture and Society 28(2): 101-117.

Dahlstedt M, Rundqvist M and Vesterberg V (2015) Citizenship. In: Dahlstedt M and Neergaard A (eds) International Migration and Ethnic Relations. London: Routledge, 86-114.

Dale G (2010) Karl Polanyi. Cambridge: Polity.

de los Reyes P (ed.) (2006) Om välfärdens gränser och det villkorade medborgarskapet. SOU 2006: 37. Utredningen om makt, integration och strukturell diskriminering.

Diesen C (2005) Likhet inför lagen. Stockholm: Natur och kultur.

Elsrud T (2008) Othering through genderization in the regional press. European Journal of Cultural Studies 11: 423-446.

Flyghed J et al. (2011) Varifrån kommer hotet?. Department of Criminology, Stockholm University.

Frank D (2005) Staten, företagen och arbetskraftsinvandringen. Växjö: Växjö University Press.

Garsten C and Jacobsson K (eds) (2004) Learning To Be Employable. Houndsmills: Palgrave Macmillan.

Grillo RD (1985) Ideologies and Institutions in Urban France. Cambridge: Cambridge University Press.

Hall S (1992) The west and the rest. In: Hall S and Gieben B (eds) Formations of Modernity. Cambridge: Polity Press, 275-331.

Hübinette T (2012) Words that wound. In: Loftsdóttir K and Jensen L (eds) Whiteness and Postcolonialism in the Nordic Region. Farnham: Ashgate, 43-56.

Hörnqvist M (2010) Risk, Power and the State. Abingdon: Routledge.

Jessop, B (2002) The Future of the Capitalist State. Cambridge: Polity Press.

Johannesson, L (2014) Partial judicialization of the Swedish asylum system. Presented at the NOPSA Conference, Gothenburg University.

Junestav M (2004) Arbetslinjer i svensk socialpolitisk debatt och lagstiftning 1930-2001. Uppsala: Acta Universitatis Upsaliensis.

Keskinen S et al. (eds) (2009) Complying with Colonialism. Aldershot: Ashgate.

Kings U, Ålund A and Tahvilzadeh N (2016) Contesting urban management regimes. In: Bak Jörgensen M and Garcia Agustin O (eds) Solidarity without Borders. Chicago: Pluto Press, 186-203.

Knocke W (2000) Integration or segregation?. Economic and Industrial Democracy 21(3): 361-380.

Lentin A (2012) Post-race, post politics. Ethnic and Racial Studies 37(8): 1268-1285.

Levitas R (1998) The Inclusive Society?. Basingstoke: Macmillan.

Likic-Broric B, Slavnic Z and Woolfson C (2015) Labour migration and informalisation. In: Dahlstedt $\mathrm{M}$ and Neergaard A (eds) International Migration and Ethnic Relations. London: Routledge, 227-248. 
Lindvall J (2004) The Politics of Purpose. Department of Political Science, Gothenburg University.

Loftsdóttir K and Jensen L (eds) (2012) Whiteness and Postcolonialism in the Nordic Region. Farnham: Ashgate.

Lundh C and Ohlsson R (1999) Från arbetskraftsimport till flyktinginvandring. Stockholm: SNS.

Marquand D (1997) The New Reckoning. Oxford: Polity.

Massey DS (1988) Economic development and international migration in comparative perspective. Population and Development Review 14(3): 383-413.

McCall L (2005) The complexity of intersectionality. Signs 30(3): 1771-1880.

Meidner R (1999) Manifest för full sysselsättning. Stockholm: Atlas.

Miles R (1982) Racism and Migrant Labour. London: Routledge \& Kegan Paul.

Miles R (1989) Racism. London: Routledge.

Miles R and Brown M (2003) Racism. London: Routledge.

Molina I (1997) Stadens rasifiering. Department of Cultural Geography, Uppsala University.

Mulinari D and Neergaard A (2005) A ‘black skull’ consciousness. Race \& Class 46(3): 5571 .

Mulinari D and Neergaard A (2016) From racial to racist state?. In: Ålund A, Schierup C-U and Neergaard A (eds) Reimagineering the Nation. Frankfurt am Main: Peter Lang [in print].

Neergaard A (2009) Racialisation in the labour market. In: Neergaard A (ed.) European Perspectives on Exclusion and Subordination. Maastricht: Shaker Publishing, 201-221.

Neergaard A (2016). The Swedish model in transition. In: Ålund A, Schierup C-U and Neergaard A (eds) Reimagineering the Nation. Frankfurt am Main: Peter Lang [in print].

OECD (2011) Recruiting Immigrant Workers, Sweden. Paris: OECD Publishing.

Polanyi K (1989/1945) The Great Transformation. Boston: Beacon Press.

Qvist M, Suter B and Ahlstedt S (2015) Migration. In: Dahlstedt M and Neergaard A (eds) International Migration and Ethnic Relations. London: Routledge, 38-61.

Runfors A (2003) Mångfald, motsägelser och marginaliseringar. Stockholm: Prisma.

Said EW (1978) Orientalism. New York: Vintage.

Sainsbury D (1996). Gender, Equality and Welfare States. Cambridge: Cambridge University Press.

Sandberg Å (ed.) (2013) Nordic Lights. Stockholm: SNS.

Schierup C-U and Ålund A (2011) The end of Swedish exceptionalism?. Race \& Class 53(1): 45-64.

Schierup C-U, Hansen P and Castles S (2006) Migration, Citizenship and the European Welfare State. Oxford: Oxford University Press. 
Schierup C-U, Krifors K and Slavnic Z (2015) Social exclusion. In: Dahlstedt M and Neergaard A (eds) International Migration and Ethnic Relations. London: Routledge, 200-226.

Schinkel W and Van Houdt F (2010) The double helix of cultural assimilationism and neoliberalism. The British Journal of Sociology 61(4): 696-715.

Spång M (2008) Svensk invandringspolitik i demokratiskt perspektiv. Malmö: Malmö University.

Svanberg I and Tydén M (1998) Tusen år av invandring. Stockholm: Gidlund.

Thompson Ford R (2008) The Race Card. New York: Picador.

Vesterberg V (2013) Ethnicized (un)employability. Ephemera 13(4): 737-757.

Widfeldt A (2014) Extreme Right Parties in Scandinavia. London: Routledge.

Woolfson C, Herzfeld Olsson P and Thörnqvist C (2012) Forced labour and migrant berry pickers in Sweden. International Journal of Comparative Labour Law and Industrial Relations 28(2): 147-167.

For correspondence

Magnus Dahlstedt, Department of Social and Welfare Studies, Linköping University, Kungsgatan 40, 60174 Norrköping, Sweden

Email: magnus.dahlstedt@liu.se

Anders Neergaard, Department of Social and Welfare Studies, Linköping University, Holmentorget 10, 60174 Norrköping, Sweden

Email: anders.neergaard@liu.se 